\title{
An Investigation of Empathy of Foster Families, Turkey
}

\section{Running Title: Empathy of Foster Families, Turkey}

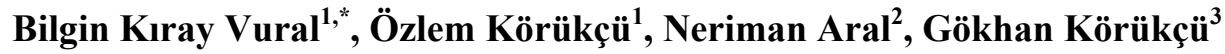 \\ ${ }^{1}$ Healthcare Services Vocational School, Pamukkale University, Turkey \\ ${ }^{2}$ Faculty of Health Sciences, Ankara University, Ankara, Turkey \\ ${ }^{3}$ Turkish Statistical Institute, Turkey
}

Copyright $(\mathrm{C} 2016$ by authors, all rights reserved. Authors agree that this article remains permanently open access under the terms of the Creative Commons Attribution License 4.0 International License

\begin{abstract}
Objectives empathy brings people closer and facilitates communication in almost all the fields of daily life. Having been an important dimension of foster care, empathetic skills should be developed in a foster family. In this study, we aimed to determine the empathic level of the foster families. Methods this cross-sectional study on foster families was performed in Turkey. Research data was collected from 124 fosters parents. Two instruments were used in the survey: the personal information form and the Basic Empathy Scale. The volunteers were chosen by applying a non-probability sampling method, i.e. the "snowball" method. The data were analyzed using SPSS statistical software, Version 18.0. Results, The foster parents had a mean age of $48.37 \pm 9.36$. Most of foster carers $(89.5 \%)$ were married. $76.6 \%$ of foster families had their own biological child, among them, 29.5\% had one, 54.7\% had two, and $15.8 \%$ had three children. The percentage of foster families that preferred female, and male children, were $76.6 \%$, and $23.4 \%$, respectively. Among the children, who had been placed in foster parent households, $42.7 \%$ aged less than 3 years, $31.5 \%$ between $4-6$ years, and $25.8 \%$ more than 7 years. The ratio of parents, who defined foster family concept as "social responsibility," "protection," "own age," and "charity" were $76.6 \%, 71.1 \%, 58.1 \%$, and $45.2 \%$, respectively. The ratio of those, who thought that to be a foster carer matured a person, was $62.9 \%$, whereas the ratio of those, who emphasized that they became role model for their environment, was $77.4 \%$. The subjects were asked to empathize with the relevant biological families, and that $59.7 \%$ gave first priority to "I want to be sure about my child's safety", $29.8 \%$ to "I want to be sure that my child is in good hands", 7.3\% to "I want to see that my child is valued". Also $56.5 \%$ of foster families pointed out that they were disturbed by the idea that one they the child might be sent back to his/her biological family. General Cronbach's alpha co-efficient of the instrument was found to be .76 . The empathy scores of foster families in this study were higher
\end{abstract}

than the average. Despite the fact that the foster families hold higher empathic skills in Turkey, it is observed that this service is still conducted with a traditional perspective.

Keywords Foster Family, Foster Children, Empathy

\section{Introduction}

The government provides the care for children in need of protection through institutional care, child adoption, and foster family care. The number of children between 0 to 18 years of age under institutional care are 12.667, and foster children are 4615, respectively; where the number of foster families is 3797 in Turkey (December 2015) [1]. In Western societies, the number of children placed under out-of-home care is at a rate of approximately 5 per 1000 in 2006-2007 [2]. Nationally, on September 30, 2013, there were an estimated 402.378 in foster care in the USA. The types of placement were $47 \%$ in nonrelative foster family homes and $28 \%$ in relative foster family homes (total $75 \%$ ) and $25 \%$ institutions, group homes, preadoptive homes and so on [3]. Percentage of use of family foster care are residential care in different countries are unlike. Respectively, foster family care and residential care are shown; Australia 91\%, 5\%; UK 80.4\%, $10.8 \%$; Romania 62.8\%, 37.2\%; Hungary 60.0\%, 40.0\%; France 53.3\%, 38.6\%; Italy 49.6\%, 50.4\%; Germany 44.0\%, $56.0 \%$ [4]. Unfortunately in Turkey, foster family care is $64 \%$ and residential care is $36 \%$.

Fifty years ego The Children Act (1948) created the modern child care service in England and Wales. However, the nature of foster family care has changed considerably over the past 50 years and, in some respects, so have the children fostered [5]. On October $2^{\text {nd }}, 1995$, Turkey started to implement Convention on the Rights of Children, which was adopted by United Nations General Assembly on20 
November1989 [6]. The modern child care service in Turkey started sixty-two years ago with the introduction of the Professional Foster Family (1952). In the Convention, particular importance is given to the children's right of living and growing primarily with his/her family, or in a proper family environment, if the former is not possible. Foster family care offers the option for children in need of out-of-home care. Foster carers have a significant responsibility in caring for vulnerable children [7]. Children staying with foster families have higher levels of motor, emotional, physical, and social development than those under institutional care. Lehman et al. [8] reported that $50.9 \%$ of the children met the criteria for one or more DSM-IV disorders, with emotional disorders (24.0\%), ADHD (19.0\%), and behavioral disorders (21.5\%). The relevant study suggest that when neglect is experienced by the babies and little children in such environments, where there is no continuous and face-to-face relationship that can substitute the parents, neglect is equivalent to violence [9]. However, the rate of children benefiting from foster care services is $30.44 \%$. It was found that the prevalence of problematic behaviors with children living together with their biological families, with foster families, and under institutional care, were $9.7 \%, 12.9 \%$, and $43.5 \%$, respectively [10]. The percentage of safe attachment of children is over $70 \%$ the society, where the same is very low $(20 \%)$ in children under institutional care [11].

The children of empathic parents take their parents as an example and use empathic skills in their relation. It is quite important that foster family have empathic tendency and use this ability to solve problems of children. When an emphatic relationship is established between the foster family and the placed child, it will also facilitate to develop a positive relationship. This is because of the fact that empathy makes people feel that they are understood and that people attach importance thereto $[12,13]$. It is imperative to establish empathy in order to relieve the nuisance of and provide assistance to an individual [14, 15]. A successful parent-child relationship is based on empathic relationship. Love constitutes the foundation of the empathic communication. This communication will help the child with developing a positive self [16]. The empathic communication form contributes in the convergence between the foster parents and the child. People, who help out other people, due to their high empathetic skills and tendencies are more well-liked by their environment [17]. It is generally accepted that empathy has two dimensions, namely, cognitive and affective. The cognitive dimension is the ability to understand how a person may feel against an incident or under certain circumstances, where the affective dimension is the ability to feel the same with the other person and communicate it there to [18]. Individuals with high empathic tendency levels act constructively within their attempts to understand others and consider the other parties during conflicting situations [19].

\section{Aim of the Study}

The purpose of this study was to identify the baseline characteristics of foster families that stipulated the problems of transition to foster care within the process and aimed to determine the empathic level of foster family in Turkey.

\section{Material and Method}

This cross-sectional study on foster families was performed in Turkey. Baseline data were obtained from face-to-face interviews with voluntary foster families $(\mathrm{N}=124)$ between January 2012 and January 2014. In the study, two instruments were used: the personal information form, and the Basic Empathy Scale (BES). The Basic Empathy Scale (BES) was originally developed by Jolliffe \& Farrington [20] and adapted into Turkish by Topcu, Erdur-Baker \& Capa-Aydın [21]. The BES has 20 items, 9 of which measure the cognitive empathy (Items 3, 6, 9, 10, 12, $14,16,19$, and 20), and 11 of which measure affective empathy (Items $1,2,4,5,7,8,11,13,15,17,18$ ) on a five-point Likert-type scale. Before the analyses, seven of the items were reverse coded. Therefore, higher scores indicated a higher level of empathy.

The authors administered the questionnaire to the foster carers. The snowball method was used as the data collection methods in order to reach out the subjects. Descriptive statistics were presented as mean, standard deviation, frequencies, and percentages, and comparison was performed with t-tests, Mann-Whitney U, Kruskal-Wallis and Variance before examining the normal distribution. Written approvals were obtained from the Scientific Ethical Board of Pamukkale University Faculty of Medicine. This research was supported and projected by the Pamukkale University Scientific Research and Funds.

\section{Results}

There were 76 females (61.3\%) and 48 males (38.7\%), with a mean age of $48.37 \pm 9.36$ years (range, 26-76). Most of foster carers $(89.5 \%)$ were married. In terms of educational status, $33.9 \%$ of the foster parents were primary and secondary school graduates, $27.4 \%$ were high school graduates, and $38.7 \%$ were university graduates. In terms of financial status, $50.0 \%$ of the subjects had an income level of TL 1001-2000, where $36.3 \%$ of the parents had an income level of above TL 2001. Results showed that 76.6\% ( $=95)$ of foster families had their own biological child. Among them, $29.5 \%$ had one, $54.7 \%$ had two, and $15.8 \%$ had three children. The percentage of foster families that preferred female, and male children, were $76.6 \%$, and $23.4 \%$, respectively. Among the children, who had been placed in foster parent households, $42.7 \%$ aged less than 3 years, $31.5 \%$ between $4-6$ years, and $25.8 \%$ more than 7 years (Table 1). 
The question, "What is the foster family concept is to you?" was directed to the respondents, and it was emphasized that multiple answers would be allowed. The ratio of parents, who defined foster family concept as "social responsibility," "protection," "own age," and "charity" were $76.6 \%, 71.1 \%$, $58.1 \%$, and $45.2 \%$, respectively. The percentage of those, who thought that to be a foster carer matured a person, was $62.9 \%$, whereas the ratio of those, who emphasized that they became role model for their environment, was $77.4 \%$.

Majority of foster carers (82.8\%) would like to have their children receive psychological support. Approximately half of foster families (45.2\%) wanted their children to receive support from social services.

The percentage of those stated that they did not feel uncomfortable when the child met with biological parents was $59.7 \%$, and the percentage of those, who replied "I would like to meet the biological parents of the child," was $20.2 \%$.

The foster family was asked to empathize with the biological family. A review of expectations by order of priority rendered that $59.7 \%$ wanted to be sure about the child's safety, $29.8 \%$ wanted to be sure that the child was in good hands, $7.3 \%$ wanted to see that the child was valued, and $3.2 \%$ wanted to regularly see the child (Fig 1). Also $56.5 \%$ of foster families have pointed out that they were disturbed by the idea that one they the child might be sent back to his/her biological family.

General Cronbach's alpha co-efficient of the Empathy Scale was found to be .76. The cognitive empathy from sub-factors was found to be .78, and the emotional empathy from sub-factors was .62. Basic Empathy Scale average points were $71.52 \pm 9.76$ in the parents. The mean cognitive empathy was $34.49 \pm 5.79$, and the mean emotional empathy was $37.03 \pm 6.08$. The results suggested that was no significant difference between female and male respondents in terms of emotional empathy, cognitive empathy sub-dimensions, and their total empathy scores ( $p>.05)$. The average scores for the items varied between $4.19-2.59$, where the standard error between .07 and .12 , and standard deviation between .87 and 1.43 .

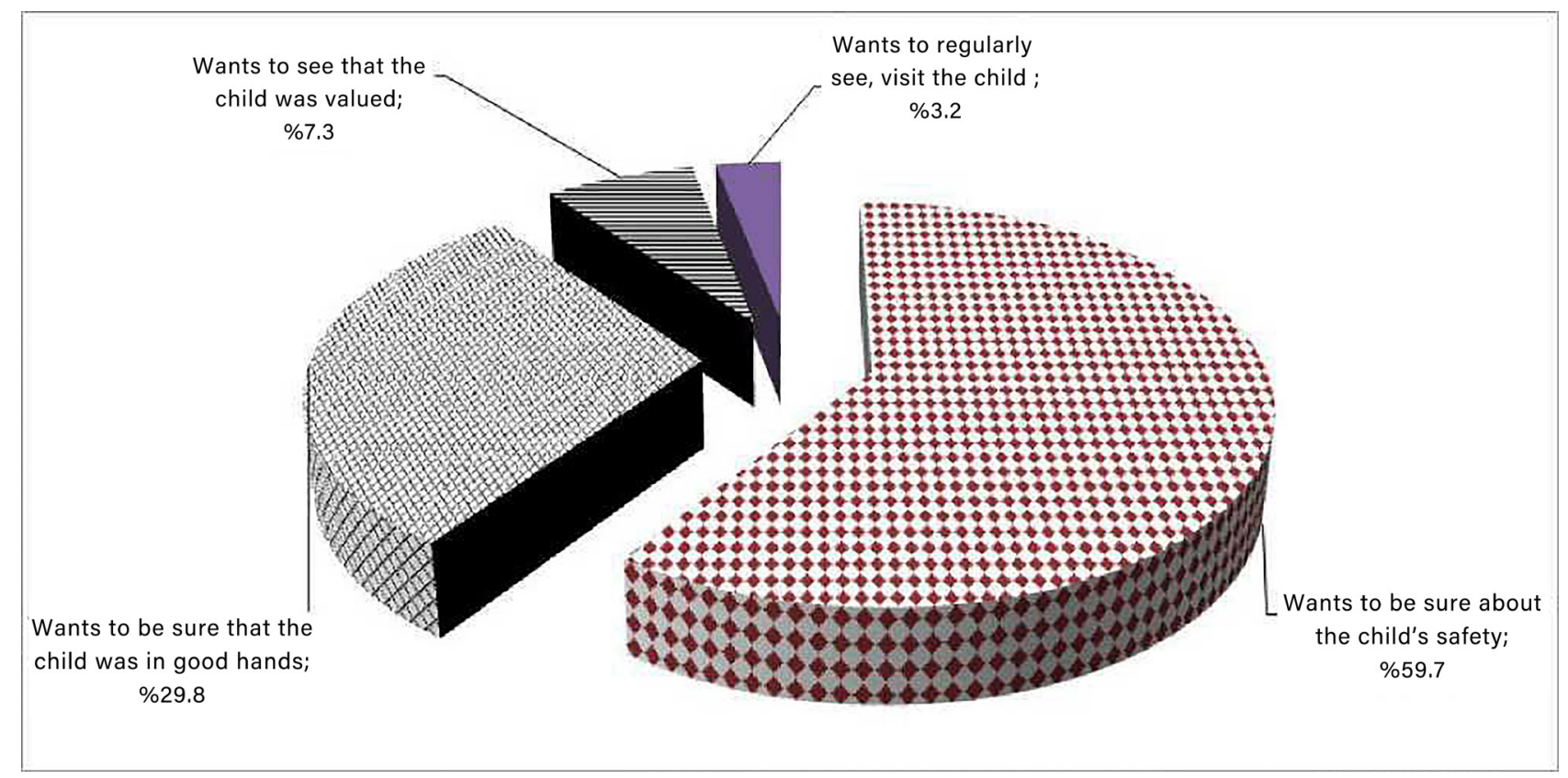

Figure 1. Empathizing with biological family-first priority 
There was a difference in terms of the age and the total scores of the items $(\mathrm{F}=3.403, \mathrm{df}=2, \mathrm{p}=.036, \mathrm{p}<.05)$. The statistical analysis suggested that $[\operatorname{LSD}(\mathrm{p}=.022)]$ the aforementioned difference stemmed from the individuals aged between 35 and 44 years. The difference between the age and cognitive sub-dimension was significant $(\mathrm{F}=3.683, \mathrm{df}=2, \mathrm{p}=.028, \mathrm{p}<.05)$, however, there was no statistically significant difference between the age and the affective sub-dimension. The difference between the educational status and the average total item scores was significant, and that the difference found to have originated from the university graduates [Tamhane's T2 $(\mathrm{p}=.034)$ ]. There was a statistically significant difference between educational status and the cognitive sub-dimension $\left(X^{2}=15.826, \mathrm{df}=4, \mathrm{p}=.003, \mathrm{p}<.05\right)$ and the affective sub-dimension $\left(\mathrm{X}^{2}=12.743, \mathrm{df}=4, \mathrm{p}=.013\right.$, $\mathrm{p}<.05)$ (Table 1).

Table 1. Distribution of the mean points of empathy scale by foster family demographics

\begin{tabular}{|c|c|c|c|c|c|}
\hline \multicolumn{2}{|c|}{ Variable } & $\mathbf{n}$ & Mean & $\begin{array}{l}\text { Standard } \\
\text { Deviation }\end{array}$ & $\mathbf{p}$ \\
\hline \multirow{2}{*}{ Gender } & Female & 76 & 3.61 & .51 & \multirow{2}{*}{$\mathrm{U}=1649.00, \mathrm{p}=.369, \mathrm{p}>.05$} \\
\hline & Male & 48 & 3.52 & .44 & \\
\hline \multirow{3}{*}{ Age, years } & 25-34 & 10 & 3.34 & .59 & \multirow{3}{*}{$\mathrm{F}=3.403, \mathrm{df}=2, \mathrm{p}=.036, \mathrm{p}<.05$} \\
\hline & $35-44$ & 30 & 3.75 & .47 & \\
\hline & 45 and $\uparrow$ & 84 & 3.54 & .46 & \\
\hline \multirow{2}{*}{ Marital Status } & Married & 111 & 3.57 & .49 & \multirow{2}{*}{$\mathrm{U}=.690, \mathrm{p}=.797, \mathrm{p}>.05$} \\
\hline & Single & 13 & 3.55 & .45 & \\
\hline \multirow{4}{*}{ Education } & Primary school & 24 & 3.47 & .38 & \multirow{4}{*}{$\mathrm{X}^{2}=14.554, \mathrm{df}=3, \mathrm{p}=.002, \mathrm{p}<.05$} \\
\hline & Secondary school & 18 & 3.38 & .43 & \\
\hline & High school & 34 & 3.44 & .47 & \\
\hline & University & 48 & 3.78 & .43 & \\
\hline \multirow{2}{*}{ Biological child } & Yes & 95 & 3.58 & .47 & \multirow{2}{*}{$U=1324.00, p=.752, p>.05$} \\
\hline & No & 29 & 3.54 & .54 & \\
\hline \multirow{3}{*}{$\begin{array}{l}\text { Work status of } \\
\text { foster families }\end{array}$} & Working & 58 & 3.64 & .06 & \multirow{3}{*}{$\mathrm{X}^{2}=4.811, \mathrm{df}=2, \mathrm{p}=.090, \mathrm{p}<.05$} \\
\hline & Housewife & 28 & 3.40 & .08 & \\
\hline & Retired & 38 & 3.60 & .07 & \\
\hline
\end{tabular}


Table 2. Distribution of the mean points of empathy scale by foster family opinions

\begin{tabular}{|c|c|c|c|c|c|}
\hline & & $\mathbf{n}$ & Mean & $\begin{array}{l}\text { Standard } \\
\text { Deviation }\end{array}$ & $\mathbf{p}$ \\
\hline \multicolumn{6}{|c|}{ The concept of foster family mean } \\
\hline \multirow{2}{*}{ Own age } & Yes & 72 & 3.56 & .49 & \multirow{2}{*}{$\mathrm{U}=1808.00, \mathrm{p}=.911, \mathrm{p}>.05$} \\
\hline & No & 52 & 3.59 & .47 & \\
\hline \multirow{2}{*}{ Protection } & Yes & 88 & 3.61 & .49 & \multirow{2}{*}{$\mathrm{U}=-1.278, \mathrm{p}=.092, \mathrm{p}>.05$} \\
\hline & No & 36 & 3.47 & .46 & \\
\hline \multirow{2}{*}{ Charity } & Yes & 56 & 3.56 & .45 & \multirow{2}{*}{$\mathrm{U}=1900.50, \mathrm{p}=.986, \mathrm{p}>.05$} \\
\hline & No & 68 & 3.58 & .62 & \\
\hline \multirow{2}{*}{ Social responsibility } & Yes & 95 & 3.61 & .47 & \multirow{2}{*}{$\mathrm{U}=-1097.00, \mathrm{p}=.97, \mathrm{p}>.05$} \\
\hline & No & 29 & 3.44 & .52 & \\
\hline \multicolumn{6}{|c|}{ Empathizing with biological family-first priority } \\
\hline \multirow{2}{*}{$\begin{array}{l}\text { Make sure that the child is } \\
\text { looked after }\end{array}$} & Yes & 99 & 3.62 & .50 & \multirow{2}{*}{$\mathrm{U}=-895.00, \mathrm{p}=.000, \mathrm{p}<.05$} \\
\hline & No & 25 & 3.39 & .37 & \\
\hline \multirow{2}{*}{ Make sure about child's safety } & Yes & 114 & 3.59 & .47 & \multirow{2}{*}{$\mathrm{U}=447.50, \mathrm{p}=.260, \mathrm{p}>.05$} \\
\hline & No & 10 & 3.34 & .60 & \\
\hline \multirow{2}{*}{ Seeing the child is valued } & Yes & 91 & 3.62 & .47 & \multirow{2}{*}{$\mathrm{U}=-1231.00, \mathrm{p}=.126, \mathrm{p}>.05$} \\
\hline & No & 33 & 3.43 & .49 & \\
\hline \multirow{2}{*}{$\begin{array}{l}\text { Request to see the child } \\
\text { regularly }\end{array}$} & Yes & 79 & 3.64 & .46 & \multirow{2}{*}{$\mathrm{U}=1432.00, \mathrm{p}=.073, \mathrm{p}>.05$} \\
\hline & No & 45 & 3.46 & .51 & \\
\hline
\end{tabular}

No statistically significant difference was found between the thoughts of the foster families regarding the foster family conception and the average item scores of the empathy scale ( $\mathrm{p}>$. 05). The foster families were asked to empathize with the biological family and state their priorities for the care of the child. The difference between 'to make sure that the child was being taken good care of' and the empathy scale was significant $(\mathrm{U}=-895.00, \mathrm{p}=.000, \mathrm{p}<.05)$. There was no statistical difference in the cognitive empathy sub-dimension, where the difference in the affective sub-dimension was statistically significant $(\mathrm{U}=-879.00, \mathrm{p}=.025, \mathrm{p}<.05)$ (Table 2).

\section{Discussion}

Due to the fact that the foster families assume great responsibilities, it is seen that such parameters as the age, educational status, marital status of the parents, and having a biological child of one's own play an important role during the decision making process for accepting the foster family status. It is observed that people apply for such a status after a certain level of maturity and stability in life is gained. Üstüner et al. [10] suggest in their study that $64.1 \%$ of foster families had their own biological child. The foster families do not want the foster family status only on the grounds of their child aspiration, but also they consider such status a social responsibility. The fact that married couples and those having their own biological child are more akin to become foster families suggests that this tendency can be attributed to improved coping skills and self-confidence. Placement of children in families that have their own biological children may induce a positive effect in the development of the placed child. Compliance of the family is thought to be easier for girls than boys in Turkey. The relevant studies suggest that foster families prefer girls $[10,22]$. In this study foster families prefer little children because their adaptation to the family is easier. The large proportion of young children in the foster care population is of concern, with children younger than five years old representing over a third of foster children in the US $(33 \%$ of 400,540$)$ [23]. The studies conducted in Turkey also revealed that early agers were preferred $[10,22]$. For the child, the family functions as an emotional castle, where all the family members are protected and looked after, loved and valued [24]. Many psychological inadaptability symptoms including moodiness, uneasiness, and ill temper may be observed in children that are deprived with the opportunity to grow up with the safety as provided 
by a family under a single roof [25]. In this study the families emphasized that the placed children were in need of psychological support. In accordance with the information provided by the carer, teacher, and the adolescents, the prevalence of problematic behaviors varied between $18.3 \%$ to $47 \%$ in children under institutional care, and that only between $9 \%$ and $11 \%$ in children growing up with their families [26]. Most children in foster care, if not all, experience feelings of confusion, fear, apprehension of the unknown, loss, sadness, anxiety, and stress [27]. Among children placed out of home, behavioral and relationship functioning is often problematic. When placed in foster care, problems tend to persist or even worsen and increase the risk of placement breakdown [28]. Foster children often suffer from post-traumatic stress disorder as well as more complex traumatic symptoms [29]. Furthermore, the behavior of children in foster care is influenced by a variety of factors including previous experiences of maltreatment and adverse parenting, as well as the impact of separation from birthparents and placement in care [30]. Many of these children have prior histories of maltreatment such as abuse and neglect, with neglect being the most common form of maltreatment and the reason for many children requiring foster care services [27]. After one year, participants recorded more often children's social history $(p=.023)$, conducted more often standardized psychosocial assessments $(\mathrm{p}=.001)$, assessed more often the medical needs of foster children $(p=.029)$, and informed foster parents more often about behavior problems of their foster child $(p=.034)$ [31]. Children in foster care are at particular risk for academic and social difficulties in school $[32,33]$ described a model of parenting which used four caregiving dimensions that were consistent with attachment theory and research: promoting trust in availability, promoting reflective function, promoting self-esteem, and promoting autonomy.

The observation of empathic attitudes in other people's lives and taking such behavior as role-model help acquisition of social sensitivity and social skills. Social functionality, emotional sensitivity and emotional regulation are all correlated with advanced level of empathic reaction $[34,35]$. As expected, the empathy scores of foster families in this study were higher than the average. Meeting with biological family is very important for the child. In this study, despite the higher empathy scores of the foster families, the percentage of parents feeling uncomfortable about child's meeting with his or her biological family was higher than expected. Based on the family structure and the cultural values in Turkey, the foster families reject to acquiesce in the relationship between the child and his or her biological family and even show resistance against development of such relations [36]. The specific needs of these adolescents with regard to: a) understanding of their family history, b) the impact of visits from and relationship with their biological family, and c) the relationship between the biological family and the foster family [37]. In this study, those, who are afraid of the possibility that the child may be returned back to his or her biological family, constitute the majority. In accordance with the importance attached to children in our culture, the majority of the foster families reject to establish a transitory relationship with the child, and expect a more permanent relationship. Even that many families give up to become foster families based on the possibility that the child may return to his or her biological family [36]. The relevant studies suggested that the empathy level of women were higher than men [21,38]. Nevertheless, the fact that there found no difference between women and men in this study, suggests that men with higher empathic skills were akin to adopt foster family status and/or the aforementioned skills were improved during the foster family process.

\section{Suggestions}

Despite the fact that the foster families hold higher empathic skills in Turkey, it is observed that this service is still conducted with a traditional perspective. A professional foster family system is required both with respect to the foster families, and the government institutions. It is suggested that the empathy levels of the individuals involved in the social support mechanism should be determined and publicity and awareness trainings should be provided to the target groups with a potential to adopt foster family status. Certain activities could be held in order to enable participants uncovering their weaknesses and strengths, revealing their existing empathic values, and increasing their self-awareness. Therefore, before becoming a foster family, parents should experience required educational activities to attain empathic skills and to determine their empathic tendencies.

\section{Strengths and Limitations}

Unfortunately, access to government databases was not granted, therefore the number of subjects was less than expected. The snowball method had to be used for data collection in order to reach out the subjects. It constituted a limitation for this study. The relatively high overall response rate supports the validity of our findings, although participation bias cannot be ruled out. Compared to the online interviews, the general strengths of face-to-face interviews included ease of participation, the possibility for obtaining detailed information from multiple informants, and more valid responses to sensitive questions.

\section{Conflict of Interest}

On behalf of all authors, the corresponding author declares that they have no competing interests. 


\section{REFERENCES}

[1] Online Available: http://cocukhizmetleri.aile.gov.tr/ istatistikl er: 2015 Y1l Sonu Verileri. Aile ve Sosyal Politikalar Bakanlığı. Çocuk Hizmetleri Genel Müdürlüğü, İstatistikler (Accessed on January 2016).

[2] Munro E, Manful E. (2012) Safeguarding children: a comparison of England's data with that of Australia, Norway and the United States.

[3] Online Available: https://www.childwelfare.govA.Vfoster.pdf Foster Care Statistic 2013, (Accessed on January 2016).

[4] del Valle J.F, \& Bravo A. (2013). Current trends, figures and challenges in out of home child care: An international comparative analysis. Psychosocial Intervention 22; 251-257.

[5] Minty B. (1999) Outcomes for long-term foster care. J Child Psychol Psychiatry, 40:991-999.

[6] Online Available: http://www.tbmm.gov.tr/komisyon/insanha klari/pdf01/137-160.pdf. Çocuk Haklarına Dair Sözleşme (1989) (Accessed on February 2014).

[7] Blythe S.L, Halcomb E.J, Wilkes L, Jackson D. (2013) Caring for vulnerable children: challenges of mothering in the Australian foster care system. Contemp Nurse, 44:87-98.

[8] Lehmann S, Havik O.E, Havik T, Heiervang E.R. (2013) Mental disorders in foster children: a study of prevalence, comorbidity and risk factors. Child Adolesc Psychiatry Ment Health, 21:7-39.

[9] Browne K.D. (2002) Child Protection. In: Rutter M, Taylor A (Eds) Child and Adolescent Psychiatry, 4th Edition. Blackwell Science, 1158-1174.

[10] Üstüner S, Erol N, Şimşek Z. (2005) Koruyucu aile bakımı altındaki çocukların davranış ve duygusal sorunları. Çocuk ve Gençlik Ruh Sağlığı Dergisi, 12: 130-140.

[11] Zeanah C.H. (2004) Bağlanma süreci ve kurumlarda yaşayan çocuklarda bağlanma bozuklukları. Prof.Dr.Mualla Öztürk Anısına XVII.Sempozyum Sunuları. Ankara Ün. Cocuk Ruh Sağlığı ve Hastalıkları Anabilimdalı Yayınları. Yayın No: IX. Ankara Üniversitesi Basımevi, 35-38.

[12] Dökmen Z. (1997) Çalışma, cinsiyet ve cinsiyet rolleri ile ev işleri ve depresyon ilişkisi. Türk Psikoloji Dergisi, 12:39-56.

[13] Alisinanoğlu F, Köksal A. (2000) Gençlerin ben durumları ve empatik becerilerinin incelenmesi. Hacettepe Üniversitesi Eğitim Fakültesi Dergisi, 18:11-16.

[14] Batson C.D, O'Quin K, Fultz J, Vanderlas M, Isen N.A.M. (1983) Influence of self reported distress and empathy on egoistic versus altruistic motivation to help. J Pers Soc Psychol, 45:706-718.

[15] Batson C.D, Fultz J, Schoenrade P.A. (1987) Distress and empathy: two qualitatively distinct vicarious, emotions with different motivational consequences. J of Pers, 55:19-39.

[16] Shapiro L.E. (2000) Yüksek EQ'lu Çocuk Yetiştirmek. Anne ve babalar için duygusal zeka rehberi.( Çeviri: Ü. Kartal ), Varlık Yayınları, İstanbul. 295.

[17] Dökmen Ü. (2012) Sanatta ve Günlük Yaşamda İletişim Çatışmaları ve Empati. Sistem Yayıncılık, İstanbul. 331.
[18] Staub E. (1987) Commentary on part I. In N. Eisenberg ve J. Strayer (Eds), Empathy and its development. Cambridge studies in social and emotional development, 195-217. New York: Cambridge University Press.

[19] Rehber E, Atıcı M. (2009) İlköğretim ikinci kademe öğrencilerinin empatik eğilim düzeylerine göre çatışma çözme davranışlarının incelenmesi. Çukurova Üniversitesi Sosyal Bilimler Enstitüsü Dergisi, 18: 323-342.

[20] Jolliffe D, Farrington D.P. (2006) Development and validation of the basic empathy scale. J Adolesc, 29:589-611.

[21] Topçu Ç, Erdur Baker Ö.E, Yeşim Çapa-Aydın. (2010) Temel empati ölçeği Türkçe uyarlaması: Geçerlik ve güvenirlik çalışması. Türk Psikolojik Danışma ve Rehberlik Dergisi, 4:174-182.

[22] Kahraman F. (2006) Türkiye'de çocuk refahı alanında Koruyucu aile hizmeti (Sakarya ve Kocaeli örneği) Yayınlanmamış yüksek lisans tezi. Sakarya Üniversitesi, Sosyal Bilimler Enstitüsü, Sakarya.

[23] US Department of Health and Human Services. The AFCARS report: Preliminary FY 2011 Estimates as of July 2012. No. 19. Washington DC: US Government Printing Office; 2011.

[24] Aral N, Köksal A. (1999) Çocukların benlik imajları kişisel ve sosyal uyum düzeylerinin incelenmesi. Çağdaş Eğitim Dergisi, 257:9-13.

[25] Yörükoğlu A. (2004) Çocuk Ruh Sağlığı, Türkiye İşbankası Yayınları.

[26] Şimșek Z, Erol N, Öztop D, Özer Özcan Ö. (2008) Kurum bakımındaki çocuk ve ergenlerde davranış ve duygusal sorunların epidemiyolojisi; Ulusal örneklemde karşılaştırmalı bir araştırma. Türk Psikiyatri Der.19:235-246.

[27] Bruskas D. (2008) Children in foster care: a vulnerable population at risk. J Child Adolesc Psychiatr Nurs, 21:70-77.

[28] Jonkman C.S, Schuengel C, Lindeboom R, Oosterman M, Boer F, Lindauer R.J.L. (2013) The effectiveness of Multidimensional Treatment Foster Care for Preschoolers (MTFC-P) for young children with severe behavioral disturbances: study protocol for a randomized controlled trial. Trials. 14:197.

[29] Scheeringa M.S, Zeanah C.H, Myers L, Putnam F. (2004) Heart period and variability findings in preschool children with posttraumatic stress symptoms. Biol Psychiatry, 14: 685-691.

[30] Kelly W, Salmon K. (2014) Helping foster parents understand the foster child's perspective: A relational learning framework for foster care. Clin Child Psychol Psychiatry, [Epub ahead of print].

[31] Oswald S.H, Heil K, Goldbeck L. (2010) History of maltreatment and mental health problems in foster children: a review of the literature. J Pediatr Psychol, 35:462-472.

[32] Pears K.C, Fisher P.A, Kim H.K, Bruce J, Healey C.V,Yoerger K. (2013) Immediate effects of a school readiness intervention for children in foster care. Early Educ Dev, 24:771-791.

[33] Schofield G, Beek M. (2005) Providing a secure base: parenting children in long-term foster family care. Attach Hum Dev, 7:3-25. 
[34] Eisenberg N, Fabes R.A, Murphy B, Karbon M, Maszk P, Smith M, Q'Boyle C. \& Suh K. (1994) The relationship of emotionality and regulation to dispositional and situational empathy related responding. J of Pers Soc Psychol, 66:776-797.

[35] Eisenberg N, Fabes R.A, Murphy B, Karbon M, Smith M. \& Maszk P. (1996) The relationship of children's dispositional empathy related responding to their emotionality, regulation, and social functioning. Developmental Psychology, 32:195-209.
[36] Karataş K. (2007) Türkiye'de çocuk koruma sistemi ve koruyucu aile uygulamaları üzerine bir değerlendirme. Toplum ve Sosyal Hizmet, 18:1-20.

[37] Fuentes-Pelâez N, Amorös P, Mateos A, BalsellsMA, Violant V. (2013) The biological family from the perspective of kinship fostered adolescents. Psicothema, 25:349-54.

[38] Eisenberg N. \& Lenon R. (1983) Sex differences in empathy and related capacities. Psychol Bull, 94:100-131. 